\title{
TINDAK PIDANA PERKOSAAN DALAM TINJAUAN HUKUM PIDANA INDONESIA
}

Oleh :

Iwan Setiawan, S.H., M.H. ${ }^{*}$

Iwan78fhunigal@gmail.com

\begin{abstract}
This paper aims to describe and analyze in depth about the crime of rape in a review of Indonesian criminal law. The regulation concerning Criminal Rape is contained in Article 285 of the Criminal Code which has elements that must be fulfilled, one of which is the absence of violence. Every element of violence is an element that distinguishes rape crimes from other morality stipulated in the Criminal Code.
\end{abstract}

Keywords: Crime of Rape, Indonesian Criminal Law

\begin{abstract}
ABSTRAK
Tulisan ini bertujuan untuk mendeskripsikan dan menganalisis secara mendalam tentang tindak pidana perkosaan dalam tinjauan hukum pidana Indonesia. Pengaturan tentang tindak Pidana Perkosaan terdapat dalam Pasal 285 KUHP yang memiliki unsur-unsur yang harus dipenuhi, salah satunya adalah tidak adanya kekerasan. Setiap unsur kekerasan adalah elemen yang membedakan kejahatan perkosaan dengan moralitas lain yang ditetapkan dalam KUHP.
\end{abstract}

Kata Kunci: Tindak Pidana Perkosaan, Hukum Pidana Indonesia

\section{PENDAHULUAN}

Salah satu masalah penegakan hukum yang harus mendapat perhatian khusus di Negara Indonesia adalah masalah tindak pidana perkosaan. Karena akibat dari tindak pidana perkosaan khusus bagi perempuan sangat merugikan. Pasca terjadi perkosaan perempuan yang diperkosa bisanya bisa mengalami trauma yang berkepanjangan, perasaan malu, tadak mampu membina hubungan dengan baik di masyarakat serta kadangkala ada stigma terhadap korban perkosaan. Penderitaan dalam arti menjadi korban jangka pendek maupun jangka panjang yang berupa kerugian fisik, mental maupun moral sosial, ekonomis.

Berdasar data yang bersumber Catatan Tahunan (CATAHU) Komnas Perempuan Tahun 2018, di ranah privat/personal, persentase tertinggi adalah

*) Dosen Tetap Fakultas Hukum Universitas Galuh 
kekerasan fisik 41\% (3.982 kasus), diikuti kekerasan seksual 31\% (2.979 kasus), kekerasan psikis 15\% (1.404 kasus), dan kekerasan ekonomi 13\% (1.244 kasus). Hal lain yang mengejutkan pada CATAHU 2018, untuk kekerasan seksual di ranah privat/personal tahun ini, incest (pelaku orang terdekat yang masih memiliki hubungan keluarga) merupakan kasus yang paling banyak dilaporkan yakni sebanyak 1.210 kasus, kedua adalah kasus perkosaan sebanyak 619 kasus, kemudian persetubuhan/eksploitasi seksual sebanyak 555 kasus. Dari total 1.210 kasus incest, sejumlah 266 kasus (22\%) dilaporkan ke polisi, dan masuk dalam proses pengadilan sebanyak 160 kasus (13,2\%). (komnasperempuan.go.id/.../2018/ SIARAN\%20PERS\%202018/Lembar\%20Fakta\%20).

Sementara dalam Ranah Publik/ Komunitas, Kekerasan di ranah publik mencapai angka 3.528 kasus (26\%), di mana kekerasan seksual menempati peringkat pertama sebanyak 2.670 kasus (76\%), diikuti berturutturut: kekerasan fisik 466 kasus (13\%), kekerasan psikis 198 kasus (6\%), dan kategori khusus yakni trafficking 191 kasus (5\%), dan kasus pekerja migran 3 kasus. Tiga (3) jenis kekerasan yang paling banyak pada kekerasan seksual di ranah komunitas adalah pencabulan (911 kasus), pelecehan seksual (708 kasus), dan perkosaan (669 kasus).

Korban tindak pidana pemerkosaan itu sendiri bukan hanya wanita yang telah dewasa, melainkan tindak pidana pemerkosaan itu sendiri sekarang bisa terjadi pada anak perempuan yang masih kecil, yang masih tidak tahu dengan apa itu hubungan seksual. Bukan hanya tidak mengenal umur korban, tindak pidana pemerkosaan juga dilakukan tidak mengenal tempat. Tempat-tempat umumpun sekarang bisa menjadi bahaya bagi wanita yang selalu menjadi korban pemerkosaan.

Perkosaan tidak bisa dipandang sebagai kejahatan yang hanya menjadi urusan privat (individu korban), namun harus dijadikan sebagai problem publik karena kejahatan ini jelas-jelas merupakan bentuk perilaku yang tidak bermoral dan keji yang selain melanggar HAM, juga mengakibatkan derita fisik, sosial, maupun psikologis bagi kaum perempuan.Perkosaan dan penanganannya selama ini menjadi salah satu indikasi dan bukti lemahnya perlindungan (pengayoman) hak asasi manusia, khususnya perempuan dari tindakan kekerasan seksual yang tergolong pada kekerasan terberat. Perlindungan terhadap perempuan telah dinyatakan pula oleh Konvensi PBB yang telah menjangkau perlindungan perempuan sampai ke dalam urusan 
rumah tangga, tidak sebatas hak perempuan di luar rumah atau sektor publik. Hal itu dapat dijadikan tolok ukur mengenai peningkatan kepedulian terhadap HAM khususnya perempuan, meskipun KUHP kita belum mengatur mengenai perkosaan oleh suami kepada istri. Perkosaan ditempatkan sebagai contoh perbuatan kriminalitas yang melanggar HAM perempuan karena lebih memposisikan keunggulan diskriminasi gender.

Tindak pidana perkosaan bukan merupakan tindak pidana yang baru tetapi merupakan tindak pidana konvensional yang banyak terjadi dimasyarakat bahkan dari tahun ketahun semakin meningkat tajam. Seolaholah pelaku tindak pidana perkosaan tidak jera akan atau tidak takut sama sekali akan sanksi yang akan diterima seperti yang tercantum dalam Pasal 285 KUHP: "Barang siapa dengan kekerasan dan ancaman kekerasan memaksa seorang wanita bersetubuh dengan dia di luar pernikahan, diancam karena melakukan perkosaan dengan pidana penjara paling lama dua belas tahun".

Jika melihat formulasi sanski yang ditertulis dalam Pasal $285 \mathrm{KUHP}$ di atas maka hukuman bagi pelaku tindak pidana perkosaan adalah sangat berat dua belas tahun, tetapi dalam kenyataannya di dalam masyarakat Hakim sangat jarang menjatuhkan sanksi pidana maksimal seperti yang tercantum didalam Pasal 285 KUHP, banyak Hakim menjatuhkan hukuman yang sangat ringan bagi pelaku tindak pidana perkosaan salah satu hal ini yang menyebakan semakin meningkatnya kasus perkosaan di masyarakat.

\section{PEMBAHASAN}

\subsection{Definisi Perkosaan}

Seiring makin majunya perkembang- an jaman, makin sarat pula beban sosial dan beban kriminalitas dalam masyarakat. Perkembangan ini membawa dampak pada kehidupan sosial dari masyarakatnya, dilain pihak pada tingkat kemajuan yang sedang dialami, juga membawa dampak timbulnya berbagai bentuk kejahatan.

Bentuk kejahatan dalam hukum pidana sebagai tindak pidana merupakan suatu perbuatan yang dilarang oleh peraturan hukum pidana dan disertai dengan adanya sanksi pidana untuk yang melanggarnya (Bambang Poernomo, 1988: 18).

Perbuatan pemerkosaan merupakan perbuatan kriminal yang berwatak seksual yang terjadi ketika seseorang manusia memaksa 
manusia lain untuk melakukan hubungan seksual dalam bentuk penetrasi vagina dengan penis, secara paksa atau dengan cara kekerasan. Dalam kamus besar bahasa Indonesia, perkosaan berasal dari kata perkosaan yang berarti menggagahi atau melanggar dengan kekerasan. Sedangkan pemerkosaan diartikan sebagai proses, cara, perbuatan perkosa atau melanggar dengan kekerasan (Tim Prima Pena, 2000: 453).

Kata perkosaan berasal dari bahasa latin rapere yang berarti mencuri, memaksa, merampas, atau membawa pergi (Hariyanto, 1997: 97). Pada zaman dahulu tindak pidana perkosaan sering dilakukan untuk memperoleh seorang istri dan tindak pidana perkosaan tidak hanya berbentuk persetubuhan namun segala bentuk serangan yang melibatkan alat kelamin yang dengan cara kekerasan dan pemaksaan oleh pelaku terhadap korban.

Tindak pidana perkosaan sebagaimana diatur dalam KUHP Pasal 285 yang berbunyi sebagai berikut: "Barang siapa yang dengan kekerasan atau dengan ancaman memaksa perempuan yang bukan istrinya bersetubuh dengan dia, karena perkosaan, dipidana dengan pidana penjara selama-lamanya dua belas tahun".

Dalam pasal 285 KUHP mensyaratkan keharusan adanya persetubuhan yang bukan istrinya disertai dengan ancaman kekerasan. Perkosaan ditandai dengan penetrasi penis kepada lubang vagina dalam hubungan seks disertai dengan ancaman dan kekeraasan fisik terhadap diri korban oleh pelaku.

Berdasarkan uraian di atas dapat diambil kesimpulan bahwa yang dinamakan perkosaan adalah :

a. Suatu hubungan kelamin yang dilarang dengan seorang wanita tanpa persetujuannya.

b. Persetubuhan yang tidak sah oleh seorang pria terhadap seorang wanita yang dilakukan dengan cara paksaan dan bertentangan dengan kemauan wanita yang bersangkutan.

c. Perbuatan hubungan kelamin yang dilakukan oleh seorang pria terhadap seorang wanita yang bukan isterinya atau tanpa persetujuanya, dilakukan ketika wanita tersebut ketakutan. 


\subsection{Jenis-Jenis Perkosaan}

Ditinjau dari motif pelaku melakukan tindak pidana perkosaan dapat digolongkan menjadi beberapa motif diantaranya :

a. Seductive Rape

Perkosaan yang terjadi karena pelaku merasa terangsang nafsu birahi, dan bersifat subjektif. Biasanya perkosaan semacam ini karena diantara kedunya sudah saling mengenal misalnya: pemerkosaan oleh pacar, pemerkosaan oleh anggota keluarga dan pemerkosaan oleh teman.

b. Sadistic Rape

Permerkosaan yang dilakukan secara sadis. Dalam hal ini pelaku mendapat kepuasan seksual bukan karena hubungan tubuhnya melainkan perbuatan kekerasan yang dilakukan oleh pelaku terhadap korban.

c. Anger Rape

Perkosaan yang dilakukan sebagai ungkapan marah pelaku. Perkosaan semacam ini biasanya disertai tindakan brutal pelakunya secara fisik. Kepuasan seksual bukan merupakan tujuanya melainkan melampiaskan rasa marahnya.

d. Domination Rape

Dalam hal ini pelaku ingin menunjukan dominasinya terhadap korban. Kekerasan fisik tidak merupakan tujuan utama korban karena tujuan utamanya adalah pelaku ingin menguasai korban secara seksual dengan demikian pelaku dapat menunjukan bahwa ia berkuasa atas orang tertuntu. Misalnya : Pemerkosaan pembantu oleh majikan.

e. Exploitasion Rape

Pemerkosaan semacam ini dapt terjadi karena ketergantungan korban terhadap pelaku, baik secara ekonomi atau social. Dalam hal ini pelaku tanpa menggunakan kekerasan fisik namun pelaku dapat memaksa keinginanya terhadap korban (Topo Santoso, 1997: 92-93). 


\subsection{Faktor-Faktor Penyebab Kejahatan Kekerasan Seksual (Perkosaan)}

Kemajuan ilmu dan teknologi, perkembangan kependudukan dan struktur masyarakat serta perubahan nilai-nilai sosial dan budaya ikut mempengaruhi dan memberikan dampak yang tersendiri kepada motif, sifat, bentuk, frekuensi, intensitas, maupun modus operandi kejahatan kekerasan. Banyak faktor secara langsung atau tidak langsung ikut memberi warna dan dampak tersendiri terhadap timbulnya kejahatan kekerasan.

Menurut Abdulsyani (1987: 44-45) terdapat dua sumber penyebab terjadinya tindakan kriminal, yaitu sumber pertama adalah faktor intern seperti sakit jiwa, daya emosional, rendahnya mental, anomi, umur, sex, kedudukan individu dalam masyarakat, pendidikan individu, masalah hiburan individu. Sedangkan faktor kedua adalah faktor ekstern, yaitu bersumber dari luar diri individu seperti faktor ekonomi, agama, bacaan dan film.

J. E. Sahetapy (1983: 82) memberikan gambaran tentang latar belakang orang melakukan kejahatan menurut hasil pengamatannya dalam praktek terutama apabila ditinjau dari segi pemasyarakatan bahwa orang yang melakukan kejahatan adalah pengaruh dari luar dirinya. Seseorang itu selalu diwarnai oleh keadaan keluarganya, lingkungan, dan masyarakat pergaulannya.

Seseorang melakukan kejahatan kekerasan dilihat dari faktor intern, yaitu disebabkan oleh mental kepribadian seseorang atau individu yang kurang baik (negatif), sehingga cenderung untuk melakukan kejahatan. Mental kepribadian ini terbentuk dari beberapa faktor antara lain :

a. Faktor agama, seseorang yang kurang mendapat siraman rohani sehingga kurang terbina mentalnya dan moralnya.

b. Faktor pendidikan, seseorang yang kurang mendapatkan pendidikan dalam melakukan sesuatu tidak mau berfikir panjang, sehingga ia cenderung melakukan perbuatan yang menyimpang atau tindakan kejahatan.

c. Faktor pergaulan yang salah dapat membentuk mental kepribadian yang kurang baik.

d. Faktor lingkungan yang kurang baik, sehingga mental kepribadiannya pun jelek.

e. Faktor ekonomi, seseorang yang kesulitan ekonomi tidak mampu mencukupi keperluan hidup, terutama para pendatang (transmigran 
ataupun urbanisasi) yang tidak mempunyai keterampilan untuk bekerja, dapat pula membentuk mental kepribadian yang jelek sehingga melakukan perbuatan yang menyimpang atau kejahatan.

Sedangkan faktor-faktor penyebab seseorang melakukan kejahatan kekerasan dari faktor eksternal antara lain :

a. Faktor korban, korban berperanan terhadap timbulnya kejahatan. Korban biasanya sebagian besar dinilai mempunyai nilai lebih dari orang-orang disekitarnya, seperti berpenampilan mewah dan mencolok, membawa barang- barang mewah dan umumnya lengah, sehingga ada niat atau kesempatan bagi pelaku kejahatan tersebut untuk melakukan aksinya, terutama kejahatan pencurian dengan kekerasan.

b. Faktor perekonomian makro yaitu terjadi krisis ekonomi dan harga barangbarang atau kebutuhan pokok meningkat, banyaknya pengangguran membuat seseorang yang dalam kondisi demikian untuk memenuhi kebutuhan hidupnya dengan jalan yang tidak benar atau melakukan kejahatan.

c. Faktor penggunaan narkotika, seseorang yang telah kecanduan obatobatan terlarang dia akan melakukan apa saja dengan jalan yang tidak benar bahkan sampai melakukan kejahatan kekerasan untuk mendapatkan sesuatu yang diinginkannya.

Perkosaan merupakan kejahatan kekerasan yang berkaitan dengan kesusilaan. Berbagai macam faktor-faktor penyebab terjadinya kejahatan tersebut, salah satunya adalah didukung oleh situasi dan kondisi lingkungan serta posisi korban berada, yang dapat memicu niat pelaku untuk melakukan kejahatan seksual (perkosaan) tersebut.Tidak jarang pula kejahatan tersebut dipengaruhi oleh faktor memanfaatkan hubungan antara pelaku dan korban, seperti hubungan darah, saudara, kerabat, dan lain-lain. Sehingga pelaku lebih mudah melakukan perkosaan tersebut karena telah mengetahui lebih dalam pihak korban.

Kejahatan perkosaan juga tidak terlepas dari faktor keadaan kejiwaan pelaku. Kejiwaan seseorang tidak hanya dipengaruhi oleh lingkungannya, tetapi juga oleh pengalaman masa lalu.Seperti halnya pelaku pernah merasa sakit hati dan depresi karena pernah mengalami suatu kejadian secara langsung maupun tidak langsung kejahatan kekerasan seksual yang membuatnya 
berinisiatif untuk melampias- kannya kepada seseorang bahkan bisa hingga beberapa orang korban.

Selain itu dapat pula faktor pemicu timbulnya pemerkosaan yang dirangsang oleh pengaruh lingkungan di sekitar pelaku, seperti halnya pelaku setelah melihat atau menyaksikan hal-hal yang berkaitan dengan pornoaksi dan pornografi dan timbul hasrat seksual pelaku. Sehingga pelaku ingin melampiaskan hasratnya tersebut dengan berbagai cara, salah satunya adalah perkosaan.

Dari setiap tindak kejahatan pemerkosaan terdapat keterkaitan antara pihak pelaku, pihak korban, dan situasi serta kondisi lingkungan yang memegang peranan masing-masing sebagai pemicu adanya suatu kejahatan kekerasan seksual, yaitu perkosaan (Eko dan Suparman, 1995: 180).

\subsection{Pembuktian Tindak Pidana Perkosaan}

Tindak pidana merupakan kasus yang kasuistis, tindak pidana perkosaan hanya dapat dibuktikan dengan alat bukti dan barang bukti bahwa tindak pidana tersebut terbukti. Dalam membuktikan telah terjadi atau belum terjadi tindak pidana perkosaan sering mengalami kesulitan.

Kesulitan dalam hal ini yaitu kesulitan tidak terdapatnya saksi yang pelaku. Serta terdakwa tidak mau mengakui bahwa kejadian tersebut tidak dia lakukan dan terdakwa selalu berdalih bahwa perbuatan tersebut dilakukan atas dasar suka sama suka. Sehingga dalam hal semacam ini hakim sulit untuk membuktikan dan memutuskan perkara.

Pembuktian unsur-unsur tindak pidana perkosaan diatur dan diancamkan pidana seperti yang tercantum dalam pasal 285 KUHP yaitu:

a. Unsur barang siapa.

b. Unsur dengan kekerasan atau ancaman kekerasan memaksa perempuan yang bukan istrinya bersetubuh dengan dia.

Unsur dengan kekerasan atau ancaman kekerasan merupakan suatu perbuatan yang dilakukan tenaga dan badan yang dapat membuat seseorang pingsan atau tidak berdaya, luka atau tertekan sehingga membuat seseorang mengalami rasa takut yang mendalam. Untuk membuktikan ada tidaknya tindak pidana pemerkosaan berpedoman terhadap alat-alat bukti yang telah diautr dalam pasal 184 KUHP yaitu: 

a. Keterangan saksi
b. Keterangan ahli
c. Alat bukti surat
d. Alat bukti petunjuk
e. Keterangan terdakwa.

\subsection{Sanksi Tindak Pidana Perkosaan dalam KUHP}

Perkosaan setiap tahunnya mengalami peningkatan yang signifikan hal ini menunjukan Sistem peradilan pidana tidak mampu berfungsi dengan baik sebagai alat general prevention artinya sebagai media pencegah kejahatan hal ini dikarena sanski pidana biasanya berupa pidana perampasan kemerdekaan yang dijatuhkan Hakim terhadap pelaku perkosaan relative ringan dan sangat bervaratif yang menyebabkan disparaty of sentencing atau disparitas dalam penjatuhan pidana (Pengertian Disparitas penjatuhan pidana menurut Molly Cheng: penjatuhan sanksi yang berbeda terhadap tindak pidana yang sama) terhadap pelaku tindak pidana perkosaan. Hal ini dimungkinkan karena di dalam Pasal 285 tidak ada straf minima khusus yang ada adalah straf maksima khusus ini berarti Hakim memilki keluasan untuk bergerak menjatuhkan sanksi dari straf manima umum yaitu satu hari sampai dua belas tahun seperti yang tercantum dalam Pasal 285 KUHP. Hakim juga tidak memilki alternative menjatuhkan sanski pidana yang lain dikarena KUHP hanya merumuskan sanksi penjara dua belas tahun bagi pelaku perkosaan tanpa ada alternative atau kumulatif dengan pidana lain semisal corporal sanction atau sanksi pidana badan (berupa cambuk atau rajam).

Sanksi yang diatur didalam pasal 285 KUHP, dijelaskan bahwa "Barang siapa dengan kekerasan atau dengan ancaman kekerasan memaksa seorang wanita yang bukan istrinya bersetubuh dengan dia, diancam karena melakukan perkosaan dengan pidana penjara paling lama dua belas tahun". Dengan pasal 291 KUHP ayat 2 ,yaitu " Jika salah satu dari kejahatan seperti tersebut dalam pasal 285,286,287,289, dan 290 mengakibatkan kematian, maka dijatuhkan pidana penjara paling lama lima belas tahun". Maka, hukuman penjara yang dijatuhkan kepada pelaku tindak pidana pemerkosaan lebih dioptimalkan pada pidana penjara. 
Didalam KUHP Indonesia yang tercantum pada pasal $10 \mathrm{KUHP}$, dijelaskan bahwa

Pidana terdiri dari :

a. Pidana Pokok:

1. Pidana Mati

2. Pidana penjara

3. Pidana kurungan

4. Pidana denda

5. Pidana tutupan

b. Pidana tambahan

1. Pencabutan hak-hak tertentu

2. Perampasan barang-barang tertentu

3. Pengumuman putusan hakim.

Pidana penjara adalah jenis pidana pokok berupa perampasan kemerdekaan. Jesheck sebagaimana dikutip Roni (2012 : 126) mengatakan bahwa pidana penjara disebut sebagai das Riickgrat des Straffensystems (Pidana penjara dapat dijatuhkan seumur hidup atau hanya sementara waktu. Pidana penjara seumur hidup ini mempunyai arti bahwa terpidana harus menjalani pidana penjara selama hayat dikandung badan. Sehingga jenis pidana ini merupakan bentuk pidana yang bersifat permanen, poena proxima morti, artinya ; pidana yang paling dekat dengan pidana mati. Jenis pidana penjara sementara untuk selama-lamanya 20 tahun atau pidana penjara seumur hidup tidak dicantumkan terhadap delik yang diancam dengan pidana mati.

Batasan mengenai jangka waktu minimal dan maksimal, dijelaskan pada pasal 12 KUHP ;

(1) Pidana penjara ialah seumur hidup atau selama waktu tertentu.

(2) Pidana penjara selama waktu tertentu paling pendek satu hari dan paling lama lima belas tahun berturut-turut.

Pasal 285 KUHP Indonesia tentang tindak pidana perkosaan ini tidak menerapkan pidana denda, sehingga korban tidak mendapatkan secara nyata kemenangan atas kasus pemerkosaan yang menimpanya kecuali rasa puas atas dipidananya pelaku tindak pidana pemerkosaan. Sehingga, untuk kejahatan perkosaan hakim harus berinisiatif sendiri untuk bersama dengan jaksa mengusahakan adanya ganti kerugian, yaitu kompensasi dan restitusi yang adil dan sesuai dengan kemampuan yang bersangkutan. 


\subsection{Upaya Penanggulangan Kejahatan Kekerasan Seksual (Perkosaan)}

Masalah kejahatan yang selalu mengganggu keamanan dan kenyamanan sosial adalah merupakan suatu masalah yang besar bagi umat manusia diseluruh dunia. Kejahatan dapat dikatakan sebagai suatu perilaku manusia yang menyimpang, bertentangan dengan hukum, serta merugikan masyarakat, maka dari itu perlu adanya upaya penanggulangannya.

Penanggulangan kejahatan mencakup tindakan preventif dan represif terhadap kejahatan. Tindakan pencegahan atau preventif yaitu usaha yang menunjukkan pembinaan, pendidikan dan penyadaran terhadap masyarakat umum sebelum terjadi gejolak perbuatan kejahatan. Sedangkan tindakan represif yaitu usaha yang menunjukkan upaya pemberantasan terhadap tindakan kejahatan yang sedang terjadi. (Abdulsyani, 1987 : 135).

Dalam lingkungan masyarakat, dapat diupayakan upaya penanggulangan melalui pendidikan hukum (law education) yang dapat diajarkan sejak dini. Manusia dididik untuk menghormati dan melindungi hakhak asasi sesamanya, dengan cara mencegah diri dan perbuatannya yang cenderung dapat merugikan, merampas, dan memperkosa hak- hak manusia lainnya.

Pendidikan hukum itu mengandung aspek preventif dan represif, dimana bagi anggota masyarakat yang belum pernah berbuat kejahatan perkosaan adalah dikendalikan dan dididik agar tidak terjerumus dalam perbuatan jahat tersebut yang merugikan diri dan orang lain, sedangkan secara represif adalah mendidik pelaku kejahatan tersebut agar tidak mengulangi kejahatan yang sudah pernah dilakukannya. Sehingga muncul perasaan segan dan tidak berani mengulangi tindakan serupa.

Upaya lainnya dapat dilihat dari segi hukum pidana, yaitu sanksi hukum pidana yang idealnya merupakan sanksi yang bersifat ultimum remedium, yang artinya setelah sanksi lain tidak cukup ampuh diterapkan dapat dijadikan upaya penanggulangan secara represif. Sanksi hukum pidana merupakan reaksi (jawaban/solusi) terhadap terjadinya suatu delik (pelanggaran/kejahatan). Pembinaan bagi pelaku merupakan tujuan utama dalam upaya represif dalam menanggulangi kejahatan kekerasan seksual (pemerkosaan).

Upaya mencegah terjadinya pemerkosaan dengan cara mengetahui penyebab terjadinya pemerkosaan dan kemudian berikhtiar menghilangkan faktor- faktor yang menjadi penyebab tidaklah mudah. Hal ini disebabkan banyaknya faktor yang dapat menjadi penyebab terjadinya pemerkosaan. 
Meskipun demikian, upaya penanggulangan sebaiknya terus dilakukan dengan mencontoh negara-negara lain. Misalnya dengan memberi penerangan (lampu) pada tempat-tempat yang sepi dan gelap. Selain itu pemberian penyuluhan secara khusus pada masyarakat juga merupakan upaya penanggulangan yang dapat dilakukan sejak dini. (Made, 1996: 80)

Dalam rangka menanggulangi kejahatan kekerasan seksual (perkosaan), pemerintah perlu melakukan penataan kembali dan memperbaharui kebijakan dan sistem hukum terlebih dahulu yang diperuntukkan agar dapat mencegah tindak pidana dan dapat bekerja secara berkesinambungan dalam memerangi kejahatan seksual tersebut.

Barda Nawawi Arief (1996: 3) memberikan berpendapat yaitu dengan merumuskan garis kebijakan sistem hukum yang juga digunakan sebagai acuan dan tolak ukur dalam penerapan dan pelaksanaan pidana dan oleh aparat pelaksana pidana.

Dengan adanya suatu kebijakan pengaturan tersebut diharapkan tujuan hukum berupa "kemanfaatan" dapat tercapai, yang oleh Jeremy Bentham lebih dikonkritkan dengan teori Utilitarian.Jeremy Bentham menyatakan, "Baik tidaknya hukum diukur melalui manfaat dari hukum tersebut kepada umat manusia, yakni apakah hukum yang bersangkutan membawa manfaat yang paling besar kepada sebanyak mungkin manusia, (the greatest happiness of the greatest people) (Fuady, 2007: 25).

\section{KESIMPULAN}

Secara yuridis pengaturan mengenai kejahatan kekerasan seksual (perkosaan) diatur dalam ketentuan Pasal 285 KUHP yang memiliki unsurunsur yang harus dipenuhi, salah satunya adalah adanya kekerasan. Adanya unsur kekerasan tersebut merupakan unsur yang membedakan pemerkosaan dengan kejahatan kesusilaan yang lain yang diatur dalam KUHP. Mengenai faktor-faktor penyebab seseorang melakukan kejahatan kekerasan seksual pemerkosaan terdiri dari 3 (tiga) faktor penting, yaitu personal pelaku, korban, dan situasi. Upaya penanggulangan yang dapat dilakukan oleh masyarakat serta aparat penegak hukum dalam menanggulangi kejahatan tersebut antara lain : Dalam lingkungan masyarakat, dapat diupayakan upaya penanggulangan melalui pendidikan hukum (law education) yang dapat diajarkan sejak dini.Upaya lainnya berdasarkan hukum pidana, yaitu sanksi hukum pidana yang 
bersifat ultimum remedium, yang artinya setelah sanksi lain tidak cukup ampuh diterapkan dapat dijadikan upaya penanggulangan secara represif serta perlu diikuti dengan adanya penataan kembali dan pembaharuan sistem hukum dan kebijakan dalam hukum pidana.

\section{DAFTAR PUSTAKA}

Abdulsyani, 1987, Sosiologi Kriminalitas, CV. Remadja Karya, Bandung.

Arief, Barda Nawawi, 1996, Kebijakan legislatif Dalam Penanggulangan Kejahatan Dengan Pidana Penjara, Badan Penerbit Universitas Diponegoro, Semarang.

Fuady, Munir, 2007, Dinamika Teori Hukum, Cetakan Pertama, Ghalia Indonesia, Bogor.

Hariyanto, 1997, Dampak Sosio Psikologis Korban Tindak Pidana Perkosaan Terhadap Wanita, Pusat Studi Wanita Universitas Gajah Mada, Jogjakarta

Pena, Tim Prima, 2000, Kamus Besar Bahasa Indonesia, Gitamedia Press, Jakarta.

Poernomo, Bambang, 1988, Asas-Asas Hukum Pidana, Ghalia Indonesia, Jakarta.

Prasetyo, Eko dan Suparman Marzuki, 1995, Pelecehan Seksual, Fakultas Hukum Universitas Islam Indonesia, Yogyakarta

Roni Wiyanto, 2012. Asas-Asas Hukum Pidana Indonesia, Mandar Maju. Bandung,

Sahetapy, J.E., 1983, Kejahatan Kekerasan Suatu Pendekatan Interdisipliner, Sinar Wijaya, Surabaya.

Santoso, Topo, 1997, Seksualitas dan Pidana, In Hill, Jakarta.

Weda, Made Darma 1996, Kriminologi, Raja Grafindo Persada, Jakarta. 